Article

\title{
Eternity in Low Earth Orbit: Icons on the International Space Station
}

\author{
Wendy Salmond ${ }^{1}$, Justin Walsh ${ }^{1}\left(\mathbb{D}\right.$ and Alice Gorman ${ }^{2, *} \mathbb{D}$ \\ 1 Department of Art, Chapman University, Orange, CA 92866, USA; salmond@chapman.edu (W.S.); \\ jstpwalsh@chapman.edu (J.W.) \\ 2 Department of Archaeology, Flinders University, Bedford Park, SA 5042, Australia \\ * Correspondence: alice.gorman@flinders.edu.au
}

Received: 15 October 2020; Accepted: 10 November 2020; Published: 17 November 2020

\begin{abstract}
This paper investigates the material culture of icons on the International Space Station as part of a complex web of interactions between cosmonauts and the Russian Orthodox Church, reflecting contemporary terrestrial political and social affairs. An analysis of photographs from the International Space Station (ISS) demonstrated that a particular area of the Zvezda module is used for the display of icons, both Orthodox and secular, including the Mother of God of Kazan and Yuri Gagarin. The Orthodox icons are frequently sent to space and returned to Earth at the request of church clerics. In this process, the icons become part of an economy of belief that spans Earth and space. This practice stands in contrast to the prohibition against displaying political/religious imagery in the U.S.-controlled modules of ISS. The icons mark certain areas of ISS as bounded sacred spaces or hierotopies, separated from the limitless outer space beyond the space station walls.
\end{abstract}

Keywords: International Space Station; iconography; hierotopy; material culture; sacred space; cosmonaut

\section{Introduction}

How the perspective of being outside the world —-that is, in space—changes personal approaches to spirituality among space travelers has been the subject of numerous studies (e.g., Suedfeld 2006; Weibel 2016, 2020; Weibel and Swanson 2006). Accounts of the "overview effect" attest to its powerful impact on individuals who experience it (White 1987). This phenomenon has become a marker of space culture, an elite experience available only to the fewer than 600 humans who have ever ventured beyond Earth. However, religious practices are also manifested in more mundane ways inside space stations, including the International Space Station (ISS). The display of icons among other imagery on the walls of the Zvezda module, in the Russian Orbital Segment of ISS, represents a conscious effort to imbue certain physical spaces with the qualities of terrestrial sacred spaces familiar to Orthodox believers. Moreover, the passage of icons between Earth and the Zvezda module shows an entanglement of cosmonauts' personal beliefs with terrestrial political agendas.

The International Space Station Archaeological Project began in 2015 as the first comprehensive study of the material culture of a human habitat in space. For the last twenty years, ISS has been the only permanent human occupation of space. The first module, Zarya, was launched in 1998, and the station now consists of 16 modules from Russia, the United States, Japan, and the European Space Agency. The Russian service module Zvezda ("Star") was launched in 2000. It contains key life support systems for the Russian crew and a docking station for Soyuz and Progress spacecraft.

Since we are unable to travel to the site to make observations in person, we have developed innovative methods to study the culture of ISS (Walsh and Gorman 2020). Chief among these is the examination of historic photographs. NASA maintains an archive of hundreds of thousands of images 
spanning the entire twenty-year occupation of the space station to date, including from the Russian Orbital Segment of which Zvezda is the main component. A sample of these images has been made available to the public through the agency's Flickr page (https://www.flickr.com/photos/nasa2explore/). These photographs are "born digital" and therefore have associated metadata giving the time and date of their creation. Arranging them in chronological order allows changes in the configuration and function of various spaces over time to be tracked.

The evidence in this article is a series of 48 photographs taken in Zvezda between 2000 and 2014. These images show that crew members adorned the module's aft wall with various items, including flags, mission patches, photos, paintings (landscapes, churches, and icons of saints), relics, religious symbols, and toys. The purposeful display of objects, especially images, in Zvezda is the continuation of a phenomenon that can be observed in Russian space stations at least since Salyut 5 in 1976 and developed through Salyut 6, Salyut 7, and Mir (Walsh et al., forthcoming). The kinds of images displayed vary from expedition to expedition, reflecting the evolution of contemporary Russian terrestrial culture-for example, in the transition from Soviet to Orthodox and nationalist symbols at the time of the collapse of the Soviet Union in 1991. The launch of icons specifically, and their return to Earth, is often documented by Russian news media, allowing us to track the dynamic nature of the Zvezda display. This display reveals the interplay between personal and institutional, even state-sponsored, expressions of faith, exemplified by the variable function of the aft wall as an "icon corner" of the kind found in adherent Russian domestic spaces; or an iconostasis, an integral part of Orthodox churches.

\section{Defining Hierotopy}

The concept of hierotopy, first developed by Alexei Lidov in 2001, is a method to recognize and evaluate the special connotative nature of religious spaces and how they are brought into being by human action. Although the concept of hierotopy is applicable across all cultures and times, Lidov has focused on the "spatial icons" of Byzantium and early Russian Orthodoxy. It seems particularly apt for the framing of Russian activity on ISS, where "space icons" have come to occupy a central place.

In Lidov's formulation, hierotopy refers to the formal construction of a sacred space. It is the product of deliberate action imbued with abstract, performative, and creative (though not necessarily "aesthetic") qualities, as well as tangible, "object-centered" ones. Hierotopy goes beyond the mere conceptualization or recognition of a space as having sacred qualities or the initial "divine inspiration" to articulate the space by means of structures, images, or holy objects; both of these aspects fall instead under the rubric of hierophany, a necessary preliminary stage to hierotopy. Key components of a hierotopy include the topographical definition of a space-demarcation of its boundaries-that is recognized as symbolically distinctive within a religious belief system; the arrangement of the structural components and/or their decoration; and the performance of specific activities (whether repeated or unique). All of these components together work to reify and activate the sacred nature of the space (Lidov 2006).

The behaviors of cosmonauts, in traveling to receive icons as part of terrestrial ceremonies at Orthodox churches, bringing them to ISS, arranging them on display in various configurations, producing photographs and videos to document and broadcast the icons, and then returning them to Earth, seem to be a clear example of hierotopic practice. From the very first Expedition (or group of crew) in November 2000, the aft wall of the Zvezda module was a locus for the display of icons. A small icon of Saint Theodor of Tiron was placed "high" on the wall in a central position between two gray fuse boxes and two red vent covers ${ }^{1}$.

1 The microgravity environment of ISS means that there is neither "up" nor "down". However, the Zvezda module was designed with a two-tone color system to help the crew orient themselves, with olive green surfaces on the side facing toward Earth (nadir) and beige surfaces on the walls and the side of the module facing away from Earth (zenith). The consistent orientation of the photographs, as well as the orientation of the items displayed on the wall, indicates that crew members 
A photograph of Sergei Krikalev exercising before the aft wall shows that the placement of the icon visibly transformed an area whose use was otherwise indistinguishable from others in the module, with equipment and electrical cords randomly scattered about (Figure 1). Krikalev and Yuri Gidzenko, the two Expedition 1 cosmonauts, had both served on Mir and so were continuing a practice of visual display that had developed on previous Soviet-Russian space stations (Walsh et al., forthcoming). On subsequent expeditions, the upper part of the aft wall continued to be the location where most icons were placed, often with a gold or gilt Orthodox cross. At various times, icons of the Mother of God with Child, Christ Pantocrator, Saint Nicholas, and Saint Sergius of Radonezh were placed, alone or together, on the wall. The Kazan Mother of God appeared most frequently, in 25 of the 48 photographs. A small painting of the cathedral at the Troitse-Sergieva Lavra, one of Orthodox Russia's most important monastic centers with close ties to Russia's space program, often appeared off to one side, especially in the first decade of Zvezda's occupation. In a set-back area below, which we refer to as the "niche," portraits of the Soviet space heroes Yuri Gagarin (the first human to orbit Earth in 1961), Konstantin Tsiolkovsky (the "father of rocket science"), and Sergei Korolev (the original leader of the Soviet space program) were placed, joined occasionally by icons, copies of the New Testament, and the golden cross mentioned above (Figure 2).

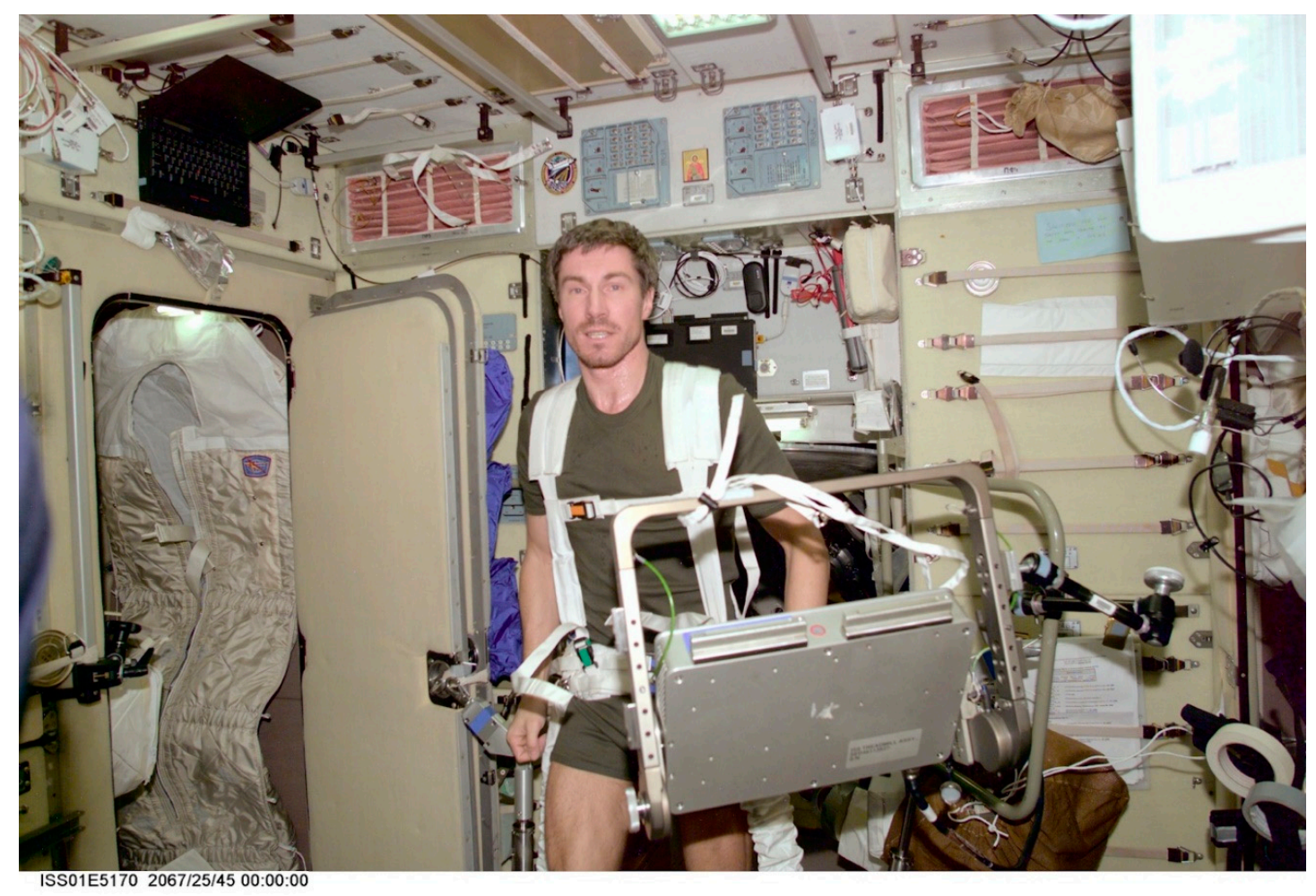

Figure 1. The Zvezda module in 2000, showing an icon of Saint Theodor of Tiron.

tend to treat nadir as "down" and zenith as "up". Our use of directional descriptors in this article, including "high" and "low", reflect this convention. 


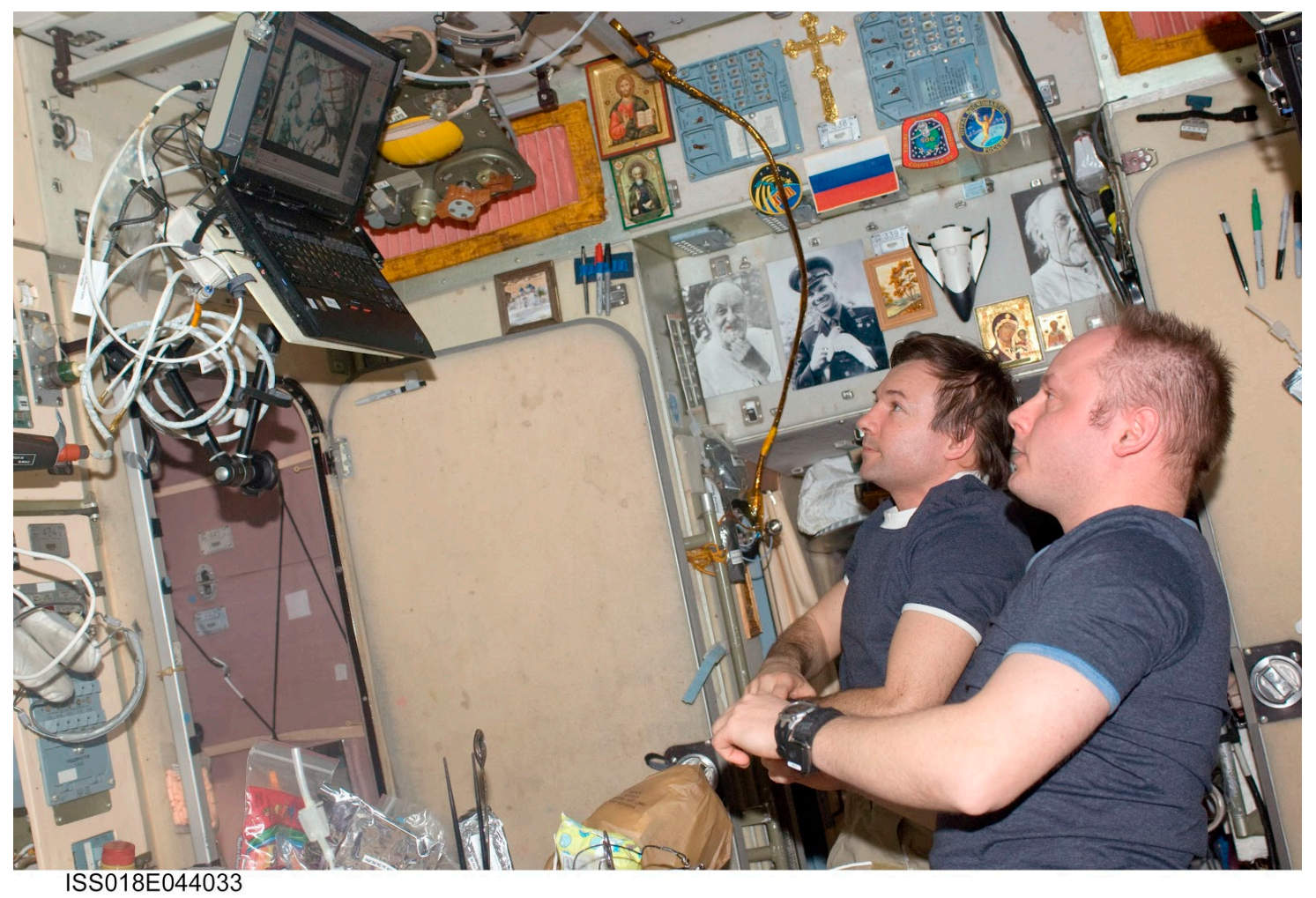

Figure 2. The space heroes Konstantin Tsiolkovsky and Yuri Gagarin displayed in the "niche" of Zvezda's aft wall.

Zvezda was not designed to accommodate icon displays. There are no obvious cues from the architecture of the space to indicate that this is an appropriate or desirable place to display sacred images, nor are there visible frames or fasteners. However, the inherent symmetry and centrality of the aft wall's design - properties that made it an effective backdrop for photo documentation and broadcasts back to Earth-also marked it out as a potential locus for creating a hierotopy within Zvezda's cramped multipurpose space. The selection of this part of the wall to mirror the public/private display of icons, in emulation of Russian churches and homes, is likely to have been a crew choice reflecting not only long-standing cultural traditions but also changes in post-Soviet society. Just as terrestrial icons began to actively circulate through pilgrimages, processions, and rituals of healing and blessing after the fall of Communism, so, too, the constant changing of images in Zvezda shows them to be replicating these participatory rituals, while also introducing a new element: the conferral of sacred aura upon icons that performed the feat (podvig) of a journey to space and back, thus undergoing a sort of rite of passage before returning to Earth. The photographs taken on Zvezda show how a sacred space has been imprinted on a technological surface, transforming the space around it by association. It is what Lidov calls a dynamic hierotopy, "adapting its elements according to an individual's perception-some aspects of the spatial entity could be accentuated or temporarily downplayed" (Lidov 2014, p. 78). Positioned on the threshold between outer space and the environment of Zvezda, and continually responding to pressures from terrestrial communities and authorities, the display of icons in the niche can be seen to act as "a kind of pivot in forming a concrete spatial environment" (Lidov 2014, p. 63).

\section{Terrestrial Politics and Celestial Artifacts}

The complex nature of post-Soviet church-state relations and their extension into outer space is central to understanding the dynamic presence of icons on ISS and the extent to which they have 
served to create a hierotopy ${ }^{2}$. With the fall of the Soviet Union in 1991, a series of collaborations between the Russian space agency Roscosmos and the Patriarchate of the Orthodox Church signaled a reversal of the atheist rhetoric that had characterized the Soviet conquest of space since Gagarin's mission in 1961. Typical of that rhetoric was the new exhibit developed by Leningrad's Museum of the History of Atheism and Religion, housed in the former Kazan Cathedral, immediately following the mission. Titled "Soviet People Conquer Space," it featured sections on Tsiolkovsky, Sputnik, and Gagarin. "Religion taught that man is an 'earthworm' and cannot fly 'like an angel'," the museum didactics read. "Science has realized the dream of people to conquer the element of air. It was not a 'divine miracle,' but bold thinking and inspired labor that gave man mighty wings to vanquish space and time" (Nauka i religiia 1961, p. 85). In the state-run museums which opened to celebrate the Space Age in the Soviet era, the three space heroes presented a master narrative of "technocratic progress, social harmony and national enlightenment" (Siddiqi 2005, p. 101).

Three decades later, the juxtaposition of the three space heroes' portraits with icons on Russian modules created a visual counter-argument that science and faith were compatible. Rumors circulated that Gagarin was a believer, with proponents pointing to his pre-flight visits to the Troitse-Sergieva Lavra (Petrov 2013). Interviews with cosmonauts revealed that a number of them had been believers even $^{3}$ in the Soviet period. Patriarch Alexy II, head of the Russian Orthodox Church from 1990 to 2008, was a key figure in institutionalizing these changes. As the first patriarch to serve after the fall of Communism, Alexy II faced the task of restoring a church badly damaged during the Soviet years. His tenure was committed to normalizing relations between secular and religious spheres and to fostering global peace initiatives, while also taking a hard line on other faiths suspected of trying to make converts among the Orthodox. During his patriarchate close ties were forged between Roscosmos and the Orthodox Church, resulting in the first of many officially sanctioned transports of icons into orbit.

In July 1995, as part of "Project Anastasia-The Hope of Peace," two print icons of Saint Anastasia, one Orthodox, the other Roman Catholic, were sent with the Patriarch's blessing "on a peace mission" to the Mir station (mir meaning both "peace" and "world" in Russian). Venerated as a protector against wars between nations and a saint common to both East and West, Anastasia represented an extension of the Soviet space program's official rhetoric of leading the family of nations toward world peace. The two icons appear in a photo of the Russian cosmonauts Gidzenko and Adveev and European Astronaut Corps (ESA) astronaut Reiter in the Mir Core Module, on either side of the photo of Gagarin in his space helmet (Figure 3).

2 For a detailed account of the Orthodox Church's active engagement with the Russian nuclear and military complex, see (Adamsky 2019).

3 For instance, Yuri Lonchakov commented, "Some people are amazed that cosmonauts believe in God. It's the Soviet stereotypes at work. But we are ordinary people, if earlier we had to conceal our faith, today we can talk about it openly", https://foma.ru/yurij-lonchakov-otkryityij-kosmos.html (accessed on 10 October 2020). 


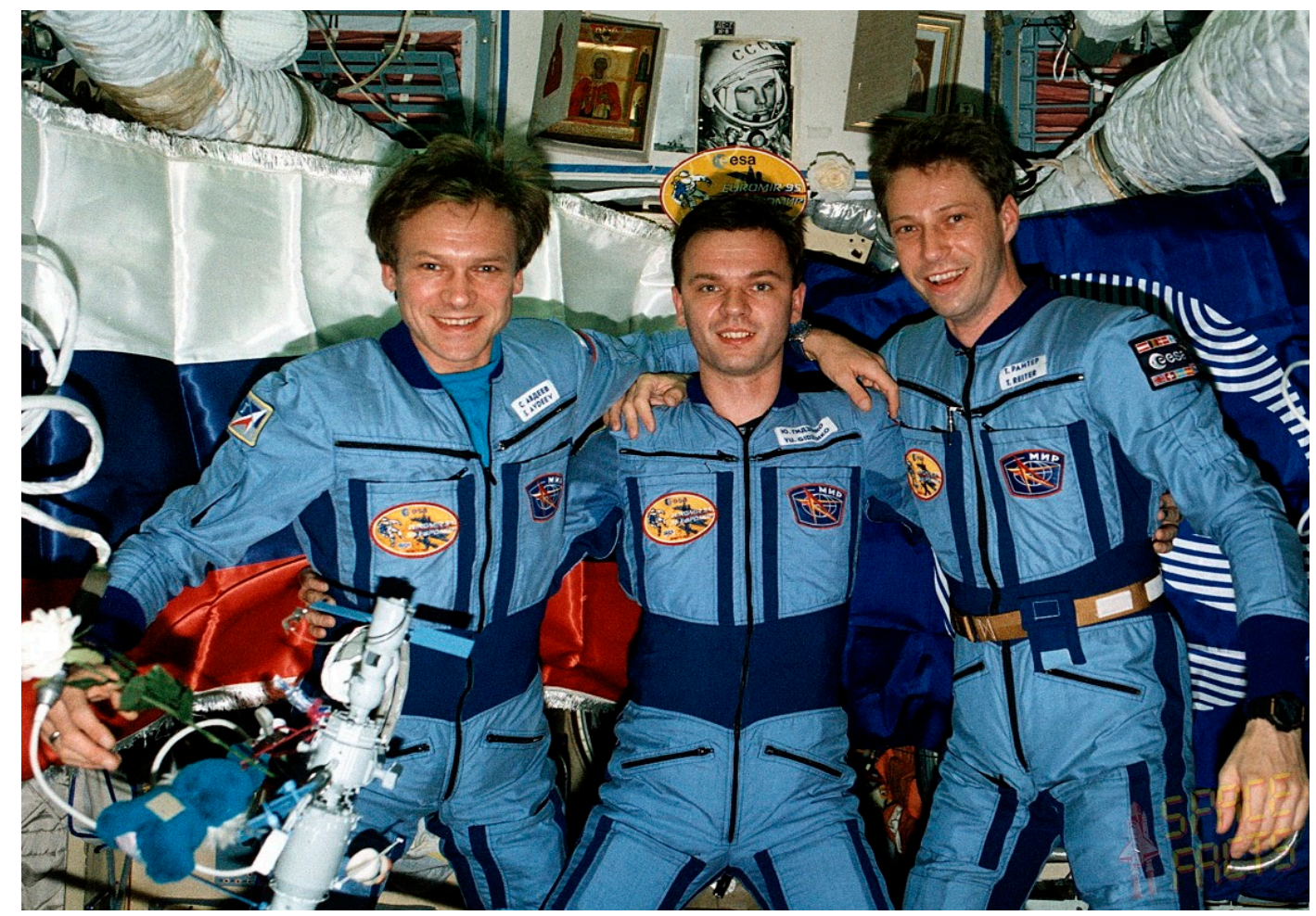

Figure 3. The icons of Project Anastasia on the Mir TM-22 mission.

The symmetry of the composition stresses the importance of the moment, as the three men enact a ritual of international cooperation in a space sanctified by the icons' presence. It also affirms the exceptional significance of Gagarin's image as one of continuity between old and new regimes. Even the placement of the "EuroMir 95" mission patch, directly lined up with Gagarin and Gidzenko's heads, conveys a quasi-hieratic meaning to the moment. In this image from Mir, and in all subsequent arrangements of Gagarin's image on ISS, a new layer of meaning was thus added to the single, unambiguous atheist reading possible before 1991. As for the two icons, they returned to Earth after seven months and were taken on a pilgrimage to the places associated with Saint Anastasia in Europe. Imbued with a new spiritual power by their exposure to a divinely created cosmos, these icons established an important precedent in the cult of space-flown objects.

This official gesture by the Patriarch may have emboldened crewmembers to add their own icons to the spot where the patriarchal visitors had been ${ }^{4}$. Between 1996 (Mir-22) and 1997 (Mir-23), a tiny icon most likely of St. Nicholas appeared on the aft wall, perhaps brought by the commander, Vasily Tsibliev. Later that year (Mir-24) a second icon of the Mother of God was added. Even so, there was still a certain degree of informality in the way images were organized in and around the niche. In a 1998 photo, images of Gagarin and Tsiolkovsky occupy the niche, while just outside it on the wall to the right is a calendar with an icon of Christ on the cover. Another photo shows an icon calendar in close proximity to an upturned vodka bottle and a stuffed toy. The presence of icons did not erase the space's domestic and recreational functions, emphasizing a point of commonality with the domestic "icon corner".

4 According to Adamsky (2019, pp. 64-65), in 1994, Valery Poliakov took his own small icon of the Kazan Mother of God into space, and since the beginning of Project Anastasia, it has become regular practice among the cosmonauts to bring personally meaningful icons. 
While the first icon appeared on ISS in November 2000, the practice of bringing icons into space became especially visible in $2004^{5}$. The ecumenism exhibited by the official inclusion of the Roman Catholic icon of Saint Anastasia on Mir did not last. That year, the renewed importance of icons in national life was made clear by the high-profile return to Russia of a revered icon of the Kazan Mother of God that had been smuggled out of the country during the 1917 Revolution and acquired by the Catholic Church. The Patriarch had rebuffed Pope John Paul II's efforts to return the icon in person, and the episode of its eventual return was considered a victory for Russian religious and patriotic feelings (Allen 2004). Anti-Catholic sentiments were running high, as the Western church attempted to leverage the overturn of state-sanctioned atheism to expand its foothold in Russia (Balzer 2010, p. xv). Just six weeks later, a copy of the Kazan icon, together with an icon of the Archangel Michael, was sent to the station on Soyuz TMA-5, evidently on the initiative of the head of Roscosmos, Anatoly Perminov (Novikova 2004). Then in early December, Perminov requested an audience with the Patriarch to discuss what part ISS might play in the country's preparations for the celebration of the sixtieth anniversary of Victory Day in 2005; also under discussion was the church's role in plans to mark the Baikonur cosmodrome's fiftieth anniversary that June. During the meeting, Perminov presented the Patriarch with the Kazan and Michael icons that had just returned from space. In doing so he established a new role for "space icons" in national life, building on patriotic narratives that had particular meaning for Russians in 2005. As Perminov asserted,

[T]he icon that has been in space will become a splendid and cherished gift for the true patriot and citizen marking this important event. Already the icons of the Kazan Mother of God and the Archangel Michael, after many times orbiting our planet, which has turned out to be so defenseless, will come to reflect the combination of traditional spiritual symbols and contemporary achievements in the field of space exploration. (Novikova 2004)

Perminov's initiatives suggest that he understood the growing political power of the church as an arm of the state, and the unprecedented role religious imagery would play in the upcoming commemorative celebrations and in public life more generally. He also alludes to the icons creating a protective circle around the "defenseless" planet, and by this feat partaking of the mystique of the cosmonaut. With this rite of passage, identical to Yuri Gagarin's, the icons were able to represent (and reconcile) both traditional spirituality and contemporary technology.

During 2005-2006, Orthodox imagery was especially visible on ISS, and there were noticeable efforts to create new traditions linking the Church and space. Taking icons to ISS became a new form of krestnyi khod (cross procession), the Orthodox tradition of taking icons and sacred relics on a procession at Easter and other solemn occasions. In 2005, Sergei Krikalev circled Earth more than 1000 times onboard ISS, together with an icon of the Valaam Mother of God (Valaam 2006). This icon was associated with an Orthodox monastery on the island of Valaam in the province of Karelia, which had been contested territory over several centuries. Miracle-working powers were attributed to the image dispatched to ISS with the Patriarch's blessing: first when the crew survived a sudden drop in air pressure, and again on the icon's return to earth when its colors were perceived to have grown brighter. As the abbot of Valaam Monastery explained, "in our era this tradition [of the cross procession] takes on new forms: we are meeting an icon that has completed an even more unusual procession.... we are seeing the dismantling of the artificial barriers that had been created between the Church, believers of different nationalities in our country, and science, particularly cosmonautics" (Kosmicheskii krestnyi khod s Valaamskoi ikonoi Presviatoi Bogoroditsy 2015).

Fostering traditions linking the church and ISS continued with an initiative called "Easter in Cosmic Space": in 2005 the Patriarch sent Easter blessings to ISS, stressing that this practice dated back

5 It is worth noting that in this early period of ISS habitation (from its beginning in 2000 until late 2008), Zvezda was the only location for permanent crew berths and that only mixed Russian-U.S. crews lived on the station. 
to the Mir station in 1995 (FOMA 2015). At Christmas services in January 2006 in Moscow's Cathedral of Christ the Savior, he informed the congregation that "the commander of the space station told him that he always wore his silver cross and that it helped him to get his job done" (Interfax 2006). And in March 2006, Alexy II gave Perminov a large gold cross, four more icons, and a New Testament, which were delivered to the station by the crew of Soyuz TMA-8. These objects are the icons and cross that feature most often in photos of the aft wall in subsequent years-Zvezda's "home icons," so to speak. Sometimes a photo or drawing of the Troitse-Sergieva Lavra near Moscow was added to the display.

A second wave of icons dispatched to ISS on short-term sojourns began in January 2008, when the Patriarch and Perminov met again to discuss future joint projects. The publicity and marketing potential of such a collaboration was also evident on the agenda, for the two men were joined by representatives of the Roscosmos TV studio and the cultural fund of the "Orthodox Encyclopedia" TV channel (Roscosmos TV Studio 2008). Perhaps this meeting marked the beginning of a more carefully scripted and "curated" presentation of ISS, one in which the aft wall would serve as a visual barometer reflecting events on Earth.

Father Iov Talats, the rector of the Cathedral of the Transfiguration in Star City (location of the Russian space agency's cosmonaut training facilities), played a central role in these initiatives ${ }^{6}$. Since 2007, Father Iov has acted as a spiritual mentor to a group of cosmonauts that includes ISS crew members Yuri Lonchakov, Fedor Yurchikhin, Alexander Samokutiaev, Valery Korzun, and Pavel Popovich (Lev 2013). In 2006, Father Iov continued a tradition, purportedly going back to Gagarin, of blessing cosmonauts at the Troitse-Sergieva Lavra before their departure. In 2008, he initiated a campaign to send holy relics into space in the care of his cosmonaut flock ${ }^{7}$. A common thread in these actions was the renewed cult of national saints associated with the idea of Holy Rus (Russia's unique history and mission as a Christian people) and with state building - a message quite distinct from the international peacemaking mission of Saint Anastasia in 1995.

The cult of relics and the traditions of pilgrimage and processions involving icons that were revived in the post-Soviet era were thus very consciously extended out into space. There is also a degree of missionary zeal in these activities, establishing Zvezda as an outpost of the Orthodox Church. More broadly, they can be seen as part of a process whereby cosmonaut traditions developed in the Soviet years were replaced by or augmented with new ones borrowed from church rituals and with strong nationalist themes ${ }^{8}$.

Roscosmos has intermittently used social media to acknowledge and normalize the presence of "religious symbols" on ISS. In this regard, the aft wall has played a central role in articulating a space that speaks directly to the intimate link between Orthodox faith, patriotism, and nation-building in post-Soviet Russia. Maksim Suraev's online diary, launched in October 2009 at the suggestion of Roscosmos's press agency, included a shot of the aft wall with the Kazan Mother of God and a small St. Nicholas icon sharing the space with the three space heroes. Other photos show the Patriarch's cross with an icon of Christ Pantocrator. As for his personal effects, Suraev wrote that he kept in his

6 On Father Iov, see (Adamsky 2019, pp. 138-41).

The first of these was a relic of Saint Sergius of Radonezh, which Yuri Lonchakov took into orbit for six months, twice carrying it out on a space walk and, at Father Iov's instruction, "periodically bless[ing] the Earth" with it. In 2010, Fedor Yurchikhin took relics of Saints Fedor Stratilat and Fedor Tiron, together with a piece of the wood in which Saint Nicholas's remains were kept when they were transferred to Bari. Anton Shkaplerov took the relics of the Moscow Metropolitans Peter and Philip, Maksim Suraev had a piece of the True Cross, and Sergei Volkov the relics of Afanasy (Sakharov) Kovrovsky, a newly canonized saint who had been a victim of Stalinist purges. In 2013, Fedor Yurchikhin took up a relic of Saint George the Victorious, worn on a chain around his neck, and in 2016 a box containing a tiny relic of Saint Serafim of Sarov was strapped to the chest of Sergei Ryzhikov (Coalson and Palveleva 2016). On its return the relic was presented to the Star City Cathedral. (https://www.pravmir.ru/osoboe-poslushanie-apostolskoe/).

8 Valery Riumin, who flew three long-duration missions on Salyut 6 in 1977, 1979, and 1980, recalls some of the Soviet rituals in his memoirs. They included an exchange of greetings with Red Square on May 1, during the International Workers Day parade, and a visit to Lenin's apartment before each flight (Riumin 1987, p. 5). Gagarin himself emphasized the new tradition of pledging to fulfill the assigned task at Lenin's mausoleum before each flight, https://foma.ru/pervyij-kosmonavto-razrushenii-xrama-xrista-spasitelya.html. 
berth a cross with a relic of the True Cross, given to him by Father Iov at Baikonur and blessed at the Troitse-Sergieva Lavra (Suraev 2009). Even when icons and relics have been temporarily absent from the "official" wall (as seems to be the case, for instance, since sometime in 2017), news reports document a steady stream of icons visiting ISS, typically sent by the abbot or abbess of a monastery or the congregation of a church. Photos of these icons are sometimes taken at the large porthole in Zvezda's floor, or in the middle of the module, where they are posed floating free in space without human presence (Figures 4 and 5). Commentary posted on Orthodox sites focuses on the revelation of God's presence in the contemplation of cosmic infinity. This placement seems to deliberately enhance the icon's "reverse perspective," a convention in icon painting which is little used in post-Renaissance art, and through this, the qualities of eternity and infinity. As Antonova (2009, p. 2) argues, the viewer's perception of the icon "can be compared to the 'vision' of God, who exists beyond time and to whom, therefore, all aspects of the objects in the world would appear at once, simultaneously." In the context of ISS, this is neither overview (White 1987) nor ultraview (Weibel 2020) but a divine view mediated by the physical presence of the icon against the backdrop of limitless space outside.

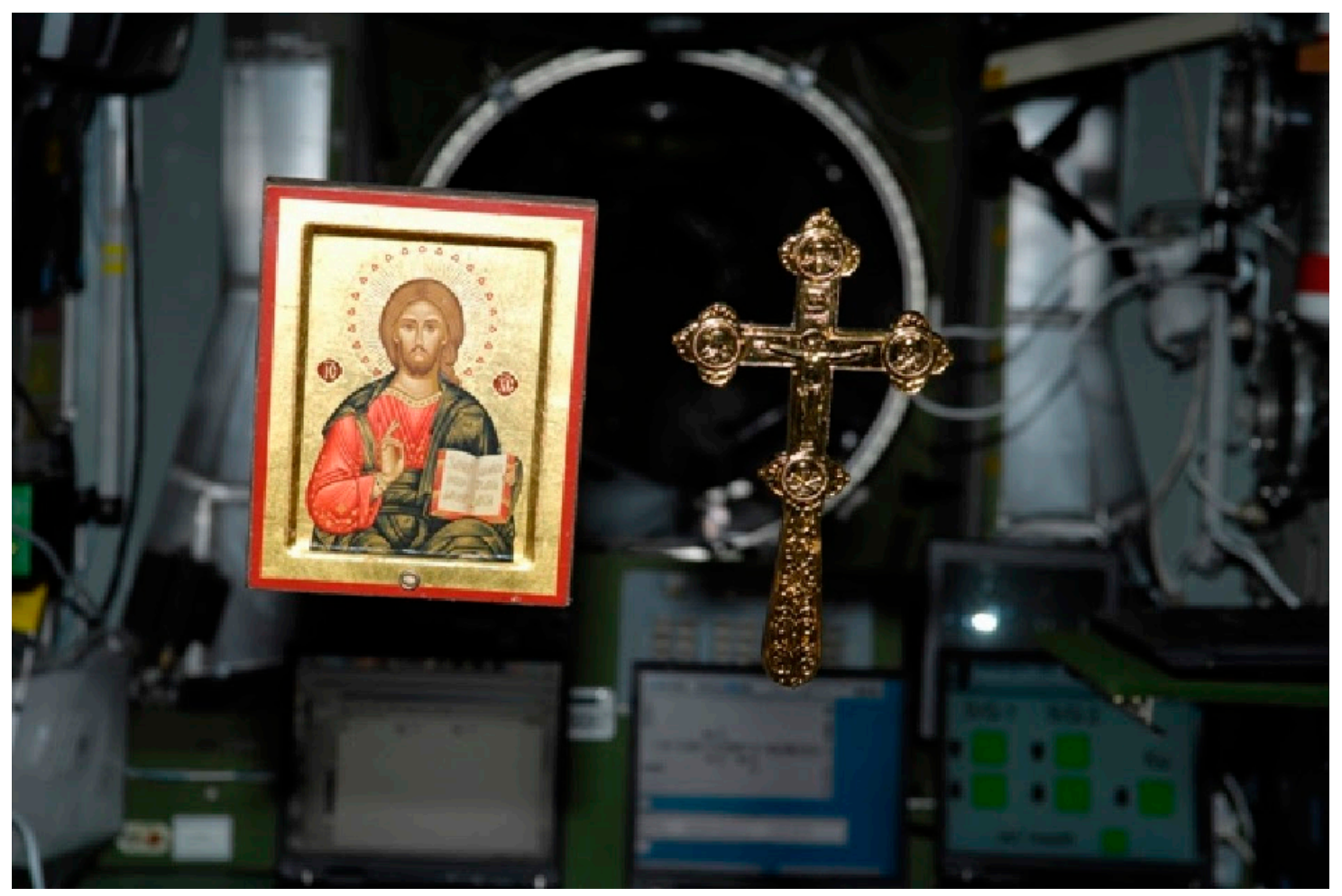

Figure 4. Icon of Christ Pantocrator and gold cross floating in front of the front hatch of Zvezda.

The transport of sacred imagery to and from ISS has continued since Alexy II's death in 2008, under his successor, Patriarch Kirill. In September 2009, Kirill blessed an icon of the Mother of God of the Sign, which went up aboard Soyuz TMA-16, remaining in orbit for 12 days (Krestnyi khod 2009). On occasion, photos taken on ISS seem to reflect a commercial dimension to the new tradition of "space icons," or at least to mirror the business aspect of icon production in contemporary Russian life. In January 2011, cosmonaut Aleksandr Kaleri was shown with three identical silver icons of the Kazan Mother of God. These were made by Aleksandr Provotorov, a member of the "Trinity" Association of Orthodox Sculptors and the initiator of a project called "A new weapon of Russians in space" (Sergii 2015). In April 2013, an online interview with Father Iov included a photo of Yuri 
Lonchakov at the porthole holding up three sets of identical color-printed images of icons of Saint Nicholas and selected saints (Figure 6) ${ }^{9}$.

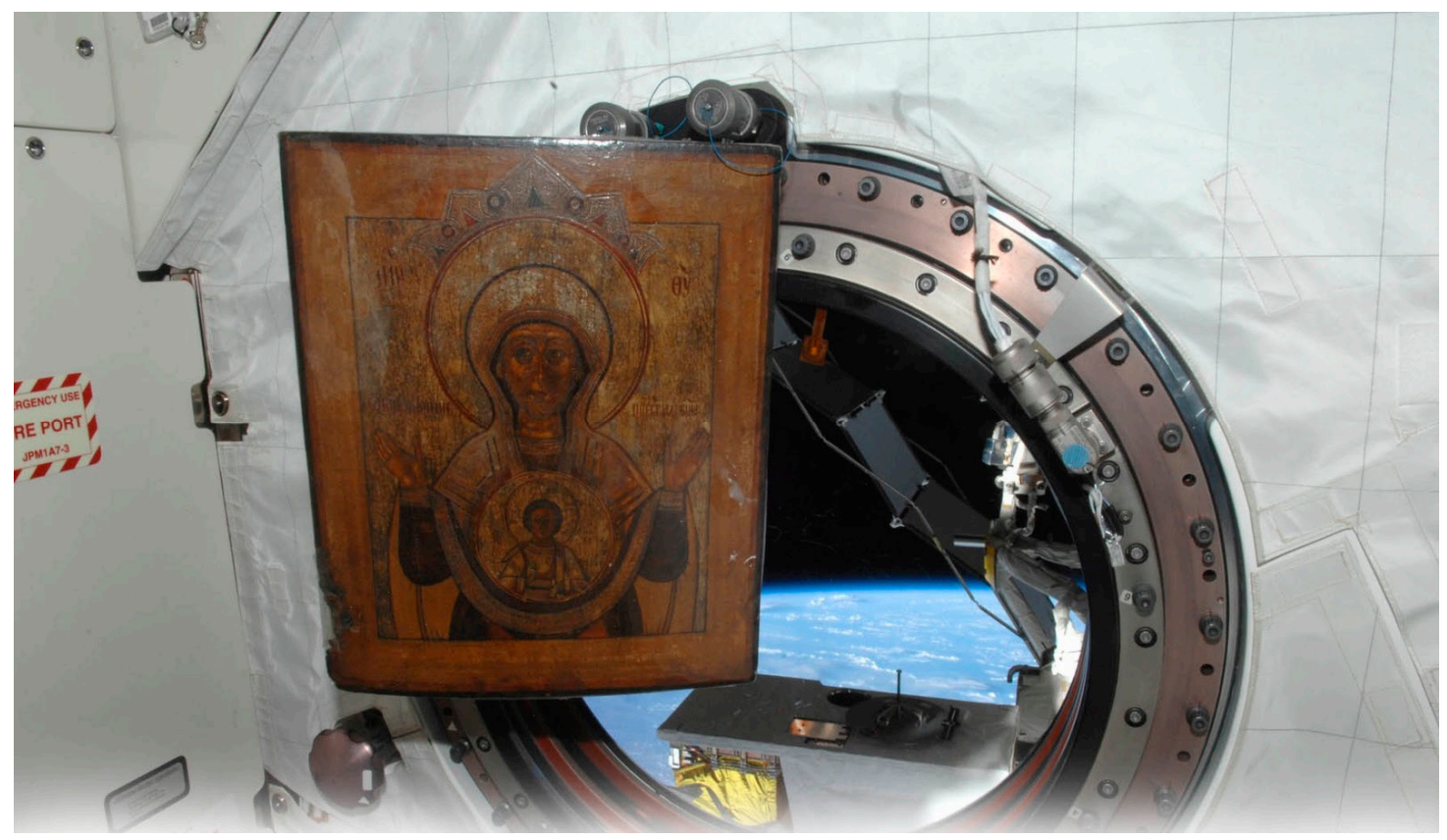

Figure 5. Icon of the Mother of God of the Sign with Earth in the background.

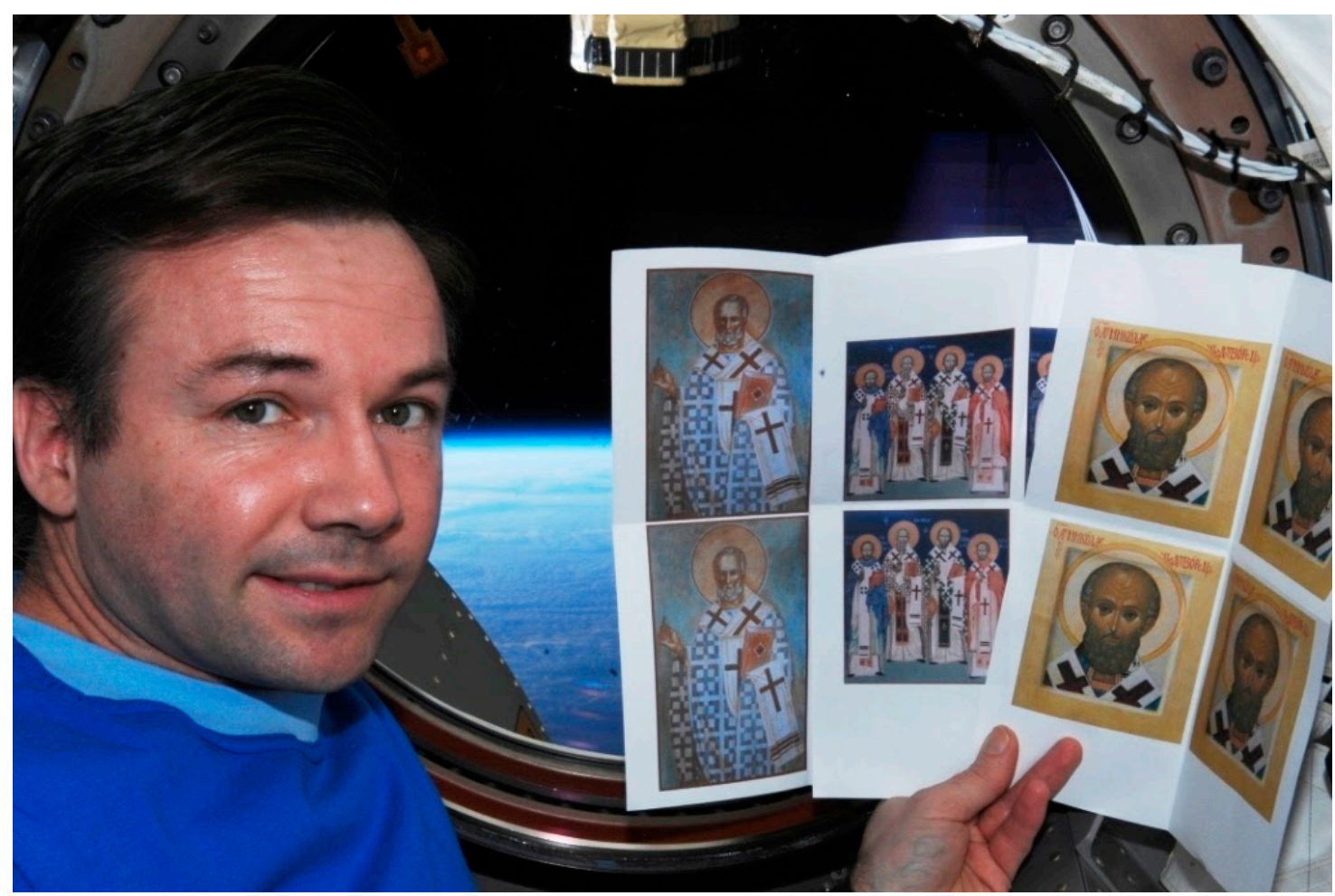

Figure 6. Cosmonaut Yuri Lonchakov with printed icons.

\footnotetext{
9 http://zvezdnyi.moseparh.ru/files/2016/10/111164.p.jpg.
} 
In both cases, the inference seems to be that the spiritual power of even mechanically produced icons is enhanced by their sojourn in space. Here, too, there is a revival of pre-revolutionary pilgrimage practices, where souvenir icons (frequently printed on tin or paper) gained immeasurably in sacred value when blessed at the shrine of a saint (Chulos 2012). News reports on such occasions emphasize the number of days each icon or relic is in space and the number of times it orbits Earth, conveying a sense of endurance, of performing spiritual and physical feats in the name of faith (Relics 216). In this sense, the icons take on qualities of the cosmonauts in enduring the rigors of space.

The presence of icons on ISS took on a more political and patriotic edge with the Russian annexation of the Ukrainian territory of Crimea in February-March 2014. On July 19 of that year, Maksim Suraev, Aleksandr Skvortsov, and Oleg Artemyev celebrated the seven-hundredth anniversary of the birth of Saint Sergius of Radonezh-one of Russia's earliest and most venerated monastic saints-with a broadcast showing them in the front end of Zvezda, holding icons of the saint (Figure 7) ${ }^{10}$. More icons hung behind them, some relocated from the aft wall, others, like the triptych of the Old Testament Trinity, clearly brought up from Earth for the occasion. The patriotic overtones of the event were heightened by the loops of orange-and-black Saint George ribbons on each cosmonaut's chest; the ribbon was an Imperial-era award for military valor that had been reactivated in post-Soviet Russia, particularly in commemorating the Great Patriotic War, as Russians call World War II. This celebration of national pride in space led to terrestrial controversy. A photograph of the scene, tweeted by Artemyev, generated some online backlash questioning the appropriateness of holding a religious celebration on ISS.

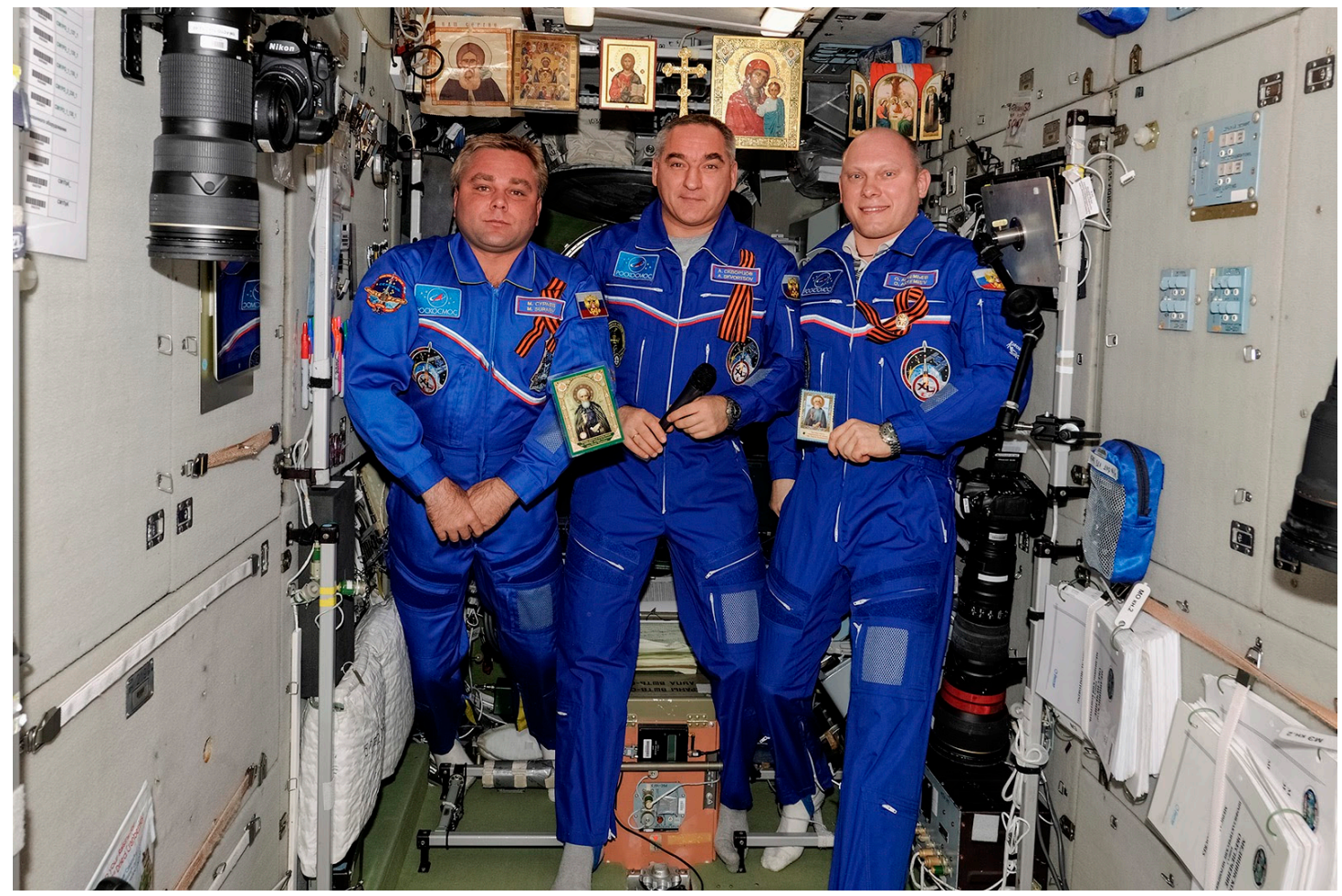

Figure 7. Cosmonauts in Zvezda, 2014, with icons of Saint Sergius of Radonezh.

The tweeted photograph was subsequently removed and replaced by an image showing the same crew members with memorabilia celebrating Soyuz-Apollo. One Ukrainian media site tweeted a doctored version of the original image that showed all of the interior surfaces of the space station

10 All four Expeditions to ISS in 2014 brought with them icons of Saint Sergius (Iz Lavry k tret'emu miru 2015). 
covered by icons and the cosmonauts given the beards and halos of Orthodox saints (Figure 8$)^{11}$. While politically motivated (note the blossoming of Saint George ribbons on the cosmonauts' uniforms), the meme demonstrated a certain understanding of how the closely shared space of the hierotopy transforms bodies. The icons become cosmonauts, the cosmonauts become saints.

\title{
Шкварки News
}

@ShkvarkiUA

\section{Follow}

Replying to @Voproskin

\section{Осталось совсем малость до такого @Voproskin @Anna_Mambyk}

\author{
Translated from Russian by $\boldsymbol{l}$ bing
}

Very little, until such @Voproskin @Anna_Mambyk

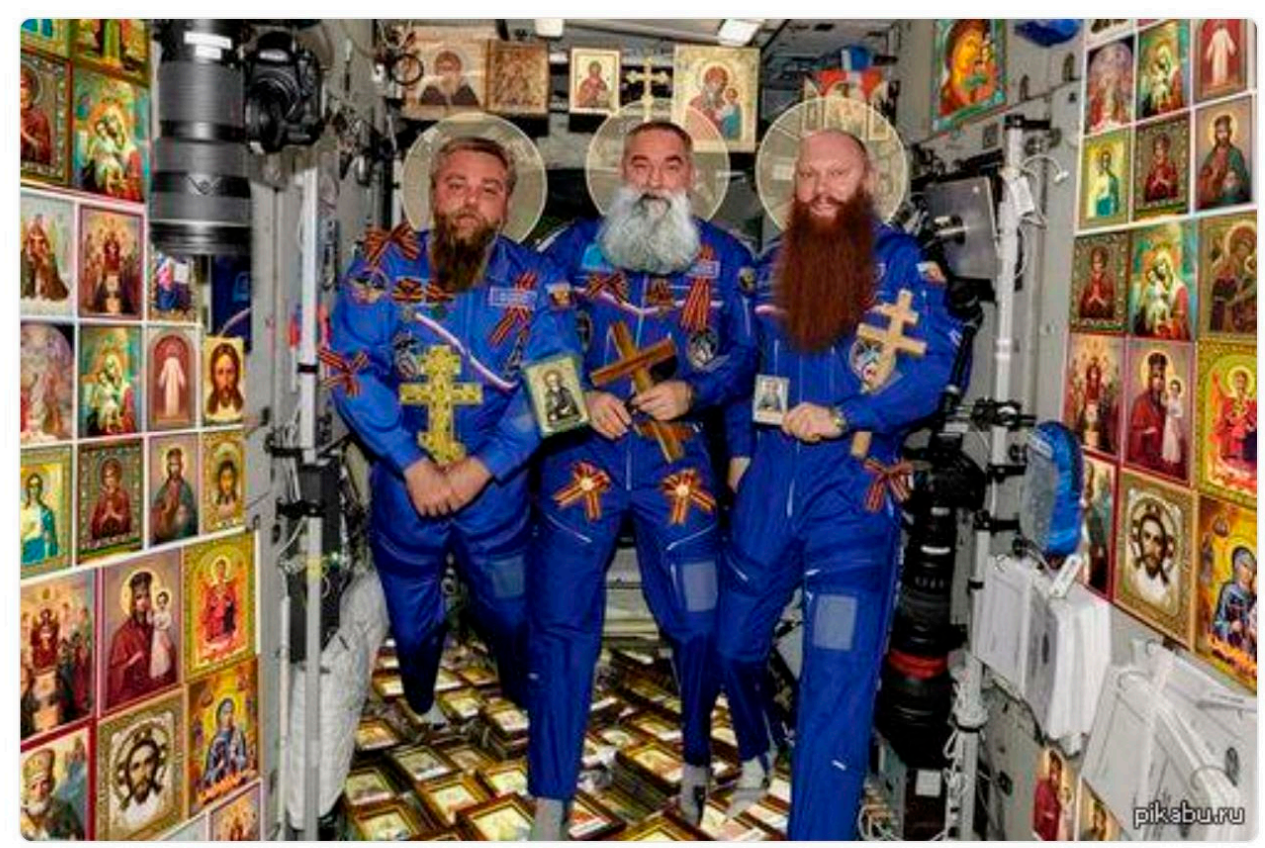

9:46 AM - 29 Nov 2014

Figure 8. A parody of Figure 7, produced by an unknown Twitter user.

\section{Synthesis}

The Russians' treatment of their space on ISS has been distinct from that of other nations housed there. No overtly religious images or symbols are on display in any other part of the station. The images and objects displayed in the Zvezda niche are both symbolic and material, contributing to the creation of a shared spiritual and social experience for the cosmonauts on ISS and reflecting deep connections to contemporary political and religious life in Russia that are most likely opaque to any but them

11 The Twitter account @ShkvarkiUA was deactivated and the media site deleted at some point subsequent to 2014. The tweet we captured was made in response to one by @Voproskin (https://twitter.com/Voproskin/status/538740093981577216) which commented on the "iconostasis". 
and their fellow Russians. Their outward, secular meaning for non-Russian (overwhelmingly U.S. and western European) crew is different from the inner, initiated meaning they hold for Russian crew, whatever their personal beliefs.

Soviet public life was saturated with ideology in every corner, and Soviet space modules replicated that with images of Lenin and other Soviet leaders among other cultural artifacts. Now that official atheism has been replaced by a strong Orthodox presence in post-Soviet Russia, the same degree of intrusion or visibility is still present on ISS, one that associates the icon with a uniquely Russian identity. The cosmonauts use the aft wall of their living space to reinforce messages for themselves as cosmonauts and Orthodox Christians, as well as making it the ever-changing backdrop for the visual messages they send back to Earth. Our findings suggest that symbolic displays once dictated by the Communist Party are now orchestrated by the Russian Orthodox Church in tandem with Roscosmos and with the cooperation of individual cosmonauts.

Russian cosmonauts have adopted recognizable patterns of display on the aft wall of Zvezda in ways that both rehabilitate icons into public life and integrate the secular space heroes into a broader symbolic field. Photos of Yuri Gagarin in a space helmet and military uniform had been fixtures of earlier space stations before ISS but apparently without a fixed location; instead, they moved about the space, tucked in among an assortment of other images and objects. It was not until ISS Expedition 4 that his photo appeared in the area above the niche along with that of Tsiolkovsky, while the famous photo of Gagarin holding a dove of peace was added to the wall in Expedition 5. Korolev first appeared together with Gagarin on Expedition 28 in January 2011. The elevation of the three men to an honorific location in the niche (sometimes drifting to the tier above) recalls the Walls of Honor (Doska pocheta) so familiar in the Soviet landscape-public displays of the portraits of war heroes, Party leaders, and exceptional citizens (Figure 9). Grouped together as the ancestors of all Soviet cosmonauts, they echo another secular Trinity that Soviet citizens would have instantly recognized: that of Marx, Engels, and Lenin (Thomas 2010). This trinitarian theme has taken on new inflections as icons have appeared alongside the space heroes in the niche of ISS, synthesizing and reconciling the Soviet past with a present where the marking of sacred space has become a matter of state importance.

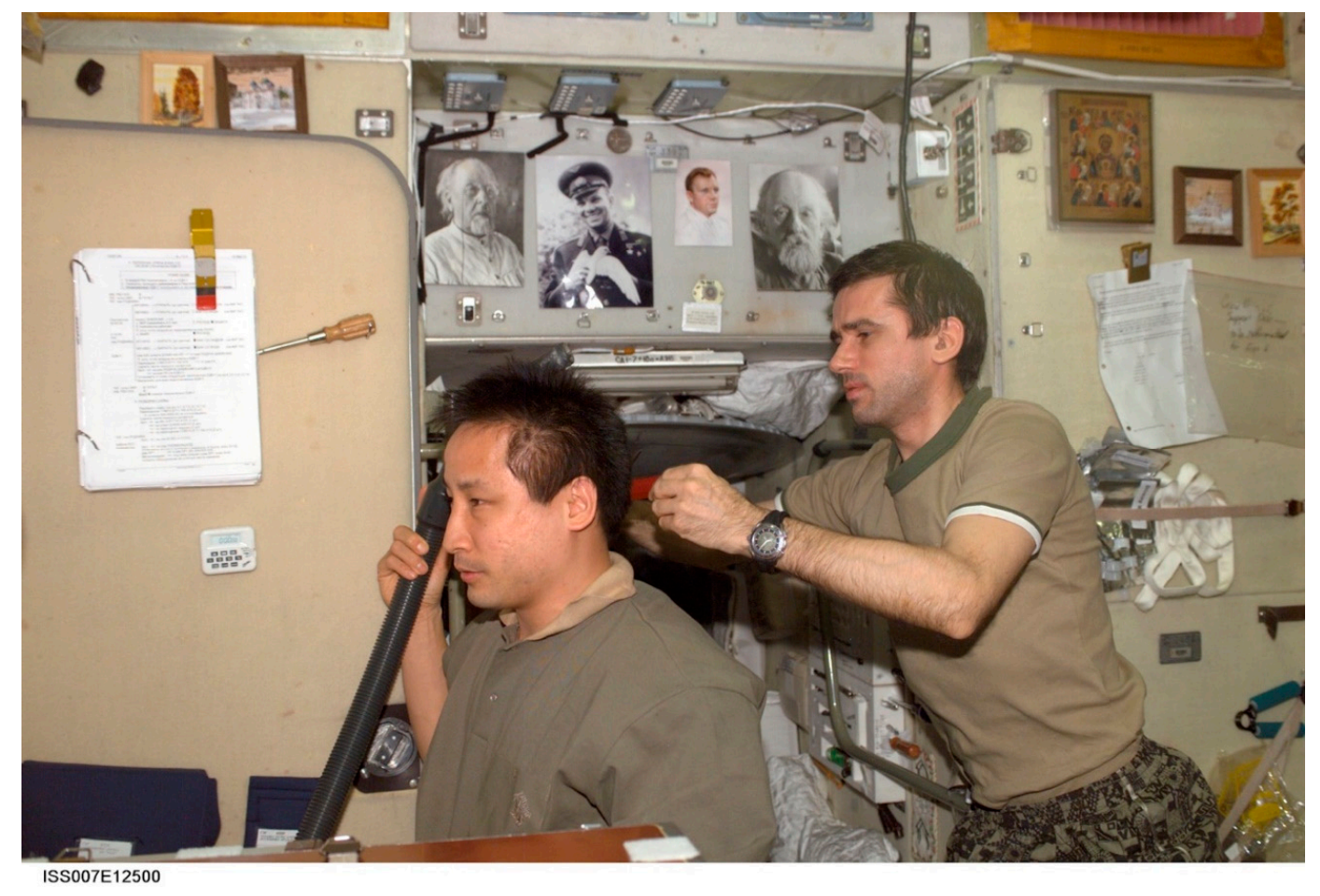

Figure 9. An "Honour Wall" in Zvezda. 
Dmitri Adamsky has shown how the Russian Orthodox Church has integrated itself into national institutions that are connected to the concept of a "Greater Russia," including nuclear military forces and the cosmonaut corps (Adamsky 2019). The sending of icons and other religious items to ISS reflects those institutional efforts, as well as the high number of Orthodox believers reported among cosmonauts. In this way, the display of religious items seems to track changes in terrestrial Russian society and culture, particularly at times of national patriotic events (V-E Day commemorations) or heightened military-political activity or stress (the 2008 conflict in Southern Ossetia, the 2014 annexation of Crimea). At the same time, the display of icons forms a distinct part of Russian space culture in the post-Soviet era. Beginning at least with Salyut 5 in 1977 and continuing through the other two Salyut stations and Mir, political and cultural secular images were regularly used to create a recognizably domestic Russian area in the part of the space station where cosmonauts spent most of their lives.

ISS combines what in terrestrial architecture tend to be separate buildings or spaces: domestic, workplace, private, public, laboratory, gymnasium, television studio, cargo hold, etc. (Figure 10). None of the segments were designed to incorporate the functions of worship or to cater to individual religious beliefs. Thus the creation of a hierotopic space on the aft wall of Zvezda has required cooperation between the crew, who willingly transport icons and other religious objects back and forth, Roscosmos, which must authorize and document every item allowed on board, and the church hierarchy on the ground, who orchestrate what is represented and when, in accordance with the liturgical calendar as well as events occurring in the geopolitical sphere. The placement and change of items over time as seen in the images analyzed is ad hoc, in the sense that the process does not follow a clear order, but also organized, in that certain types of objects seem to be clustered in various locations.

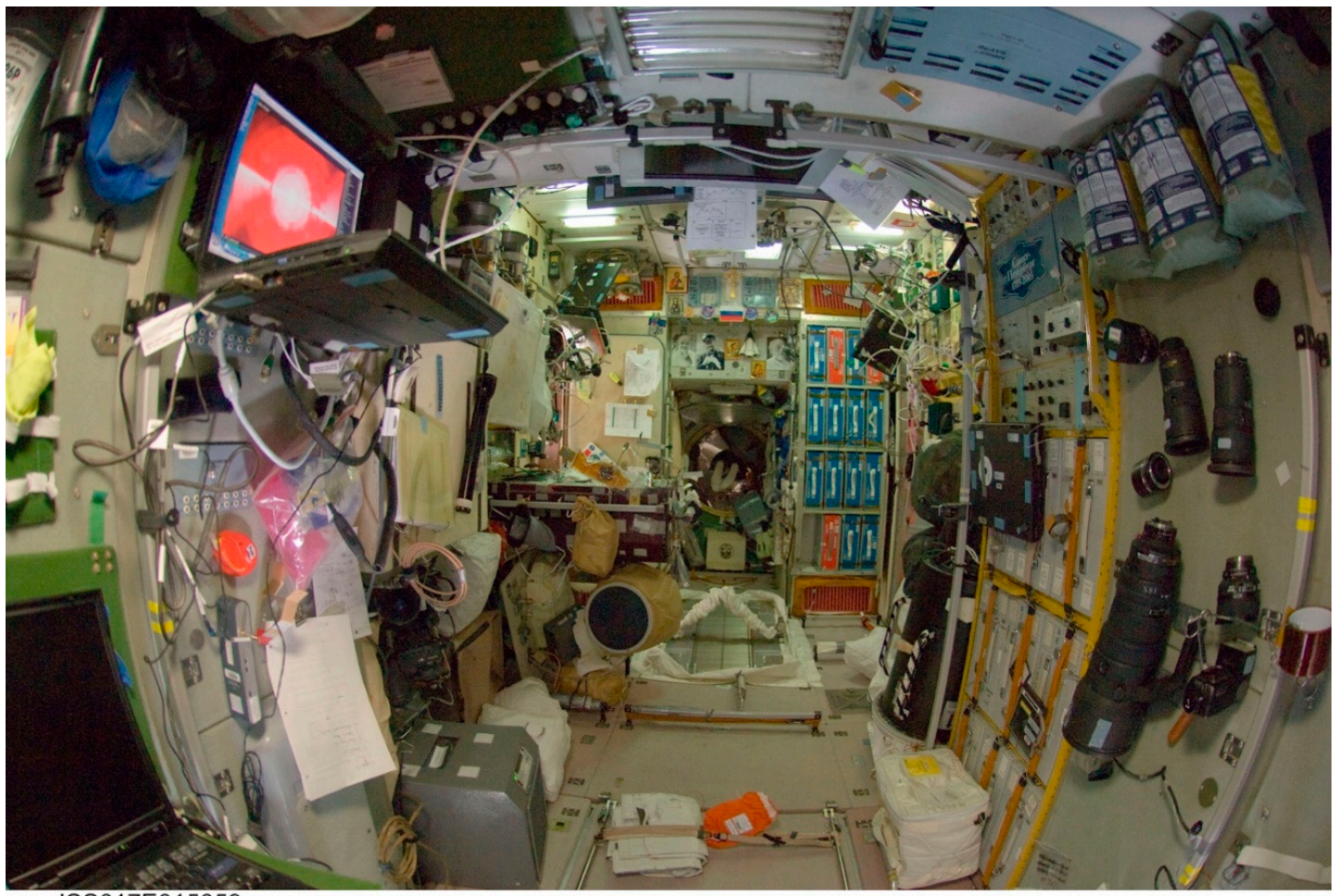

ISS017E015059

Figure 10. Sacred space in the International Space Station.

What makes the display and performances in Zvezda unique is the conflation of three usually distinct forms of hierotopy: the domestic icon corner and the public-facing iconostasis of an Orthodox church, the performance of sacred rituals in which icons play an active role, and the secular veneration of space heroes in museums. The appearance of icons, relics, religious books, and crosses in the photo database is the static record of a dynamic culture of religious observance that appears to be evolving on 
ISS. It has become a place that replicates some of the hierotopic functions of icons on Earth, including pilgrimages and cross processions, blessing the community of the faithful, and celebrating saint's days. This affirms the Orthodox belief that icons are filled with divine agency and act as intermediaries or portals connecting the mundane space of Earth with the Divine cosmos.

Author Contributions: Conceptualization: W.S., J.W. and A.G.; Data collection and analysis: J.W.; Historical research: W.S. and J.W.; Writing-original draft preparation: W.S. and J.W.; Writing: review and editing: A.G., W.S. and J.W. All authors have read and agreed to the published version of the manuscript.

Funding: This research received funding from the Australian Research Council, Grant Number DP190102747.

Conflicts of Interest: The authors declare no conflict of interest. The funders had no role in the design of the study; in the collection, analyses, or interpretation of data; in the writing of the manuscript, or in the decision to publish the results.

\section{References}

Adamsky, Dmitry. 2019. Russian Nuclear Orthodoxy. Religion, Politics, and Strategy. Stanford: Stanford University Press.

Allen, John L., Jr. 2004. Pope Returns Icon to Russia. CNN. August 28. Available online: https://edition.cnn.com/ 2004/WORLD/europe/08/28/russia.icon/index.html (accessed on 13 November 2020).

Antonova, Clemena. 2009. Space, Time, and Presence in the Icon: Seeing the World with the Eyes of God. London and New York: Routledge.

Balzer, Marjorie Mandestam. 2010. Introduction. In Religion and Politics in Russia. A Reader. Edited by Marjorie Mandelstam Balzer. New York: ME Sharpe Inc., pp. ix-xxiv.

Chulos, Chris J. 2012. Icons in motion: Sacred aura and religious identity in Late Tsarist Russia. Journal of the Canadian Historical Association 232: 176-211. [CrossRef]

Coalson, Robert, and Lilya Palveleva. 2016. Relics of Russian Orthodox Saint Set to Spend Six Months in Space. September 25. Available online: https://www.rferl.org/a/russia-space-st-serafim-relics-to-go-to-iss/28011674. html (accessed on 13 November 2020).

FOMA. 2015. Interview with Valery Korzukhin, "Paskha v Kosmose [Easter in Space]". April 12. Available online: https://foma.ru/pasha-v-kosmose.html (accessed on 1 October 2020).

Interfax. 2006. Patriarkh Aleksii Pozdravil s Rozhdestvom Ekipazh MKS [Patriarch Aleksii Sends Christmas Greetings to the Crew of ISS]. January 9. Available online: http://www.interfax-religion.ru/?act=news\&div= 8513 (accessed on 1 October 2020).

Iz Lavry k tret'emu miru. 2015. From the Lavra to the Third World. March 23. Available online: http: //stsl.ru/news/all/iz-lavry-k-tretemu-nebu (accessed on 1 October 2020).

Kosmicheskii krestnyi khod s Valaamskoi ikonoi Presviatoi Bogoroditsy. 2015. Cross Procession in Space with Valaam Icon of the Most Holy Mother of God. December 10. Available online: https://valaam.ru/publishing/ 7805/ (accessed on 13 November 2020).

Krestnyi khod. 2009. Krestnyi khod s ikonoi Bozhiei Materi "Zmanenie" vokrug zemli [Cross Procession with the Icon of the Mother of the God of the Sign around the Earth]. October 12. Available online: https://hram. zp.ua/novosti-pravoslaviya/krestnyi-hod-s-ikonoi-bozhiei-materi-znamenie-vokrug-zemli/ (accessed on 13 November 2020).

Lev, Marina. 2013. Kosmos vo slavu Bozhiiu [Space to the Glory of God]. Russian Folk Line. December 4. Available online: https://ruskline.ru/monitoring_smi/2013/04/12/kosmos_vo_slavu_bozhiyu/ (accessed on 1 October 2020).

Lidov, Alexei. 2006. Hierotopy. The creation of sacred spaces as a form of creativity and subject of cultural history. In Hierotopy: Creation of Sacred Spaces in Byzantium and Medieval Russia. Edited by Alexei Lidov. Moscow: Progress-Tradition, pp. 32-58.

Lidov, Alexei. 2014. Creating the sacred space: Hierotopy as a new field of cultural history. In Spazi e Percorsi Sacri: I Santuari, le Vie, i Corpi. Padua: Libreriauniversitaria.it Edizioni, pp. 61-89.

Nauka i religiia. 1961. Nauka i Religiia: Kratkii Spravochnik-Putevoditel' [Science and Religion: A Short Reference Guide]. Comps. M.S. Butinova and Ia. M. Pritykin; Gosudarstvennyı̆ muzei istorii religii i ateizma. Leningrad: Izd-vo Akademii nauk SSSR Leningradskoe otd-nie. 
Novikova, Inna. 2004. Patriarch Inquired about Space in Detail. Pravda. December 15. Available online: https://www.pravda.ru/faith/48992-patriarchy/ (accessed on 13 November 2020).

Petrov, Valentin. 2013. Did Yuri Gagarin Say He Didn't See God in Space? Pravmir. April 12. Available online: https://www.pravmir.com/did-yuri-gagarin-say-he-didnt-see-god-in-space (accessed on 13 November 2020).

Riumin, Valerii. 1987. God vne Zemli. Dnevnik Kosmonavta [A Year outside Earth. Diary of a Cosmonaut]. Moscow: Molodaia Gvardiia.

Roscosmos TV Studio. 2008. Kosmos i tserkov' [Space and the Church]. January 16. Available online: http://www.tvroscosmos.ru/3884/ (accessed on 13 November 2020).

Sergii, Ikona. 2015. 'Kazanskoi Bozh'ei Materi' v Kosmose [Icon of the Kazan Mother of God in Space]. November 3. Available online: https:/elitsy.ru/profile/2017/262107/ (accessed on 13 November 2020).

Siddiqi, Asif A. 2005. Privatising memory: The Soviet space programme through museums and memoirs. In Showcasing Space: Artefacts Series: Studies in the History of Science and Technology. Edited by Martin Collins and Doug Millard. London: Science Museum, pp. 98-115.

Suedfeld, Peter. 2006. Space memoirs: Value hierarchies before and after missions-A pilot study. Acta Astronautica 58: 583-86. [CrossRef]

Suraev, Maksim. 2009. Otvechaem Chitateliam: Pro Religioznye Simvoly na MKS. November 17. Available online: https://echo.msk.ru/blog/surayev_maxim/634977-echo/ (accessed on 13 November 2020).

Thomas, Andrew. 2010. Kul'tura Kosmosa: The Russian Popular Culture of Space Exploration. Boca Raton: Dissertations.com.

Valaam. 2006. Valaam vstretil 'kosmicheskuiu ikonu' [Valaam Has Greeted a 'Space Icon']. May 5. Available online: https://valaam.ru/publishing/5267/ (accessed on 13 November 2020).

Walsh, Justin St. P., and Alice C. Gorman. 2020. A methodology for research in space archaeology: The International Space Station Archaeological Project. Antiquity. [CrossRef]

Walsh, Justin St. P., Alice C. Gorman, and Wendy Salmond. Forthcoming. Space-Station Culture: An Archaeological Analysis.

Weibel, Deana L. 2016. “Up In God's Great Cathedral”: Evangelism, astronauts, and the seductiveness of outer space. In The Seductions of Pilgrimage: Sacred Journeys Afar and Astray in the Western Religious Tradition. Edited by Michael A. Di Giovine and David Picard. New York: Routledge, pp. 233-57.

Weibel, Deana L. 2020. The overview effect and the ultraview effect: How extreme experiences in/of outer space influence religious beliefs in astronauts. Religions 11: 418. [CrossRef]

Weibel, Deana L., and Glen E. Swanson. 2006. Malinowski in Orbit. Quest 13: 53-61.

White, Frank. 1987. The Overview Effect-Space Exploration and Human Evolution. Boston: Houghton-Mifflin.

Publisher's Note: MDPI stays neutral with regard to jurisdictional claims in published maps and institutional affiliations.

(C) 2020 by the authors. Licensee MDPI, Basel, Switzerland. This article is an open access article distributed under the terms and conditions of the Creative Commons Attribution (CC BY) license (http://creativecommons.org/licenses/by/4.0/). 